\title{
Geography Master's Knowledge of Learning Models that Can Establish Islamic Spatial Character Students in SMA Negeri Lombok Timur Regency, Indonesia
}

\author{
Zulti Afriza \\ Graduate Student of Geography Education, Faculty of Social Science,Universitas Negeri Padang. \\ Email : afrizazulti@gmail.com
}

\begin{abstract}
The purpose of this research is to analyze the teacher's knowledge about the learning model that can shape the spatial character of Islamic students and analyze the students' Islamic character in the geography learning model at SMA Negeri in Kabupaten Lombok Timur. This type of research uses a qualitative approach. Technique of collecting data by observation, interview and documentation, research instrument is researcher own. Technique Data analysis in this research is done with Miles and Huberman model. The result of the research shows that Jigsaw learning model can shape the spatial character of the Islamic student. The Islamic characters formed in the Jigsaw learning model are teamwork, caring, respectful of others' opinions, responsible, and independent. Islamic spatial character is not littering, planting trees as a form of environmental preservation, not picking flowers in the school environment.
\end{abstract}

Keywords: Master's Knowledge, Educational Character of the Spatial Islami.

\section{Introduction}

Character is defined as human nature in general, human nature is determined by many factors, including family environment/residence, play environment, and education through which. Thus the character is the nature of psychology, morals or character that characterizes a person or a group of people. A good character will be born from education, and a good environment by way of culture and empowerment of noble values within the educational/school environment, family environment and community environment. The process of character formation in schools is also called character education (Jammaluddin, 2013). Character education is the cultivation of essential values with learning and facilitation so that the students as individuals are able to understand, experience, and integrate the values that become core values into their personality (Sugandi, 2015). Education character of the nation is the concept of character education in Indonesia is currently born as a result of National Cultural Education Seminar and the nation's character held in Jakarta on January 14, 2010. The event resulted in the Grand Design Character Education which contains the framework of cultural process and character empowerment that will be implemented by strategy macro-scale and micro-related character development in an educational unit. One of the impact of these activities, since 2010 ago character education is encouraged again in learning in Indonesia. (Utomo, 2016).

While Spatial character is a way of view or framework of analysis that emphasizes the existence of space as emphasis. Space eksisitensi in the perspective of geography can be viewed from the structure (spatial structure), pattern (spatial pattern), and process (spatial processess). In this spatial character that needs to be considered is the spread of space usage and the provision of space that will be utilized. Analysis with the approach of human activity that is describing human activity in space. Character education is interpreted as an education that develops cultural values in the learners themselves so that they have values 
and character as their character, apply those values in their life, as members of society, and good citizens (Anwar, 2017) The implications of character in life day-to-day is a manifestation of the values of human behavior that is always associated with God Almighty, self, fellow human beings, environment, and nationality embodied in thoughts, attitudes, feelings, words and deeds based on religious norms, manners, culture, and customs. Such characters are also called Islamic characters. This means that the characters in accordance with Islamic values (Ernawati, 2017).

Islamic character is ideally applied in Indonesia, as more than $80 \%$ of Indonesians are Muslim. Especially in East Lombok regency with a population of $100 \%$ are Islamic. Islamic character is a mental attitude that directs people to do good between each other so as to create a good society and regular. Islamic character must produce noble character, a way of saying good words, and dress according to Islamic norms. According Raghib al-Asfahani, Islamic ethics in the form of ethical individual social egoism in moral motivation. That is, Islamic social ethics does not want to stifle individual authority for social (understand commutarianism) or social sacrifice for the individual (universalism). The Islamic character must be based on the ideals of justice and the freedom of the individual to do good to others, and to the environment.

Character education in schools is a system of inculcating the values of character to the citizens of the school which includes the components of knowledge, awareness or willingness, and actions to implement those values, whether to God Almighty (God), self, fellow, and nationality to become human beings kamil us. In character education in schools, all stakeholders must be involved, including the educational component itself. Character education can be integrated in learning in each subject by developing learning materials relating to norms or values in each subject, and linked to the context of everyday life so that character learning values not only on the cognitive level but touch on internalization and real practice in the lives of everyday learners in society. In developing the value and character of the students, the teacher must have the advantage in realizing the spiritual, emotional, moral, social, intellectual value in his personality, as well as having the advantages and understanding of science, technology and art according to the developed field. On the other hand teachers should have the character of discipline and professional awareness because they are responsible for disciplining learners in the school, especially in learning (Abu, 2015).

Education Unit Level Curriculum (KTSP) which is then implemented into Curriculum 2013 is a curriculum designed to provide the widest possible opportunities for schools and educators to conduct educational practices in order to develop all the potential of the students, either through the process of learning in the classroom as well as through self-development programs (extracurricular). The development of potential learners is intended to establish self-awareness about the ability or life skills, especially personal skills (personal skills) it has. Included in this case is the potential development of learners related to his character. In developing the character of learners in schools, teachers have a strategic position as the main actors. The teacher is a figure who can digugu and imitated or become an idol for learners. Teachers can be a source of inspiration and motivation of learners. Attitudes and behavior of a teacher is very imprinted in the student, so the speech, character and personality of the teacher to mirror the students. Thus the teacher has a great responsibility in producing a generation of character, cultured, and moral. Human tasks are transpormation, identification, and self-understanding, to be carried out jointly in organic, harmonious, and dynamic unity (Arthur, 2015).

Professional teachers are teachers who can develop the material with various models of learning because the learning model can be interpreted as a style or strategy undertaken by a teacher in carrying out learning activities. Learning model is very important role in the learning process, because through the selection of the right model can lead teachers to the quality of learning more effective. The implementation of the learning model includes several strategies or procedures with the hope that the desired goal can be achieved. The geography learning model is meaningful as the strategy or style that geography teacher in 
geography lesson learns to have previously planned objectives can be achieved (Bedznar, 2000). Master's knowledge is everything the teacher knows about the subject matter and in general knowledge has a predictive ability to something as a result of the recognition of a pattern, when information and data are merely capable of informing or even causing harm, knowledge is capable of directing the act, in obtaining teacher knowledge about learning model that can form Islamic character of student in SMA Negeri Regency of East Lombok done using verbal communication with one of interview technique especially with Geography teacher because based on data of BPS 2010 regency of East Lombok is regency which has highest number of population among 10 other districts in West Nusa Tenggara province with 1,105,582 inhabitants and $100 \%$ Moslems, in every village on Lombok Island has mosques and mushalls so that Lombok is known as the island of se thousand mosques. The strength of Islamic teachings in East Lombok is also reflected in the availability of educational facilities and infrastructure. The number of junior high schools as many as 287 units, consisting of 92 (32\%) SMP Negeri and $195(68 \%)$ Tsanawiyah. The total number of SMA is 171 units consisting of 50 (29\%) SMA, 101 (59\%) Aliyah and 20 SMK (12\%). (East Lombok BPS, 2010) This means that the number of students enrolled in madrasah is much greater than that of schools in public schools. Based on the above data of course provides a very big possibility for the development of Islamic character education in the life of the community of East Lombok regency considering the people who are $100 \%$ Muslim because character education will grow and develop well through religious education and social values that are in the environment around participants educated (Ikhwumelu, 2015).

\section{Method}

This research uses qualitative approach. One of the reasons for using a qualitative approach is that it can be used to discover and understand what's behind the phenomenon, which is sometimes something that is difficult to understand satisfactorily. So by using qualitative methods of data obtained more complete, more in-depth, credible and meaningful so that the objectives of the study will be achieved. The results data are presented in the form of words and not in series of numbers (Miles and Huberman, 1994). This research was conducted in SMA of East Lombok Regency. Informants in this study are all teachers who are deemed to have competence and information about research data that researchers need to provide opinions, thoughts, assessments and strengthening of teacher knowledge about learning models that can shape the Islamic character. The key informants in this research are mainly Geography teachers. The data of this study were collected by observation, interview, using interview guides, as data collection tools also did not ignore the possibility of using non-human resources of information, such as available record documents (Faisal , 1990). To avoid mistakes or mistakes that have been collected data, need to check the validity of data. Data validity checks are based on crebility criteria with triangulation techniques, observational persistence, peer checking (Moleong, 2004).

\section{Results and Discussion}

This research was conducted in East Lombok regency and the research result was obtained from 4 high schools which have conducted character education of Islamic sphere, to the four high schools such as SMAN 1 Montong Gading, SMAN I Sikur which is a high school close to coastal tourism and two SMA that is SMAN I Sembalun and SMAN I Sambelia are located close to the mountain tour and include the area of Geo Park Rinjani. Researchers conducted a direct survey of the four schools to find out the teacher's knowledge of the learning model that can shape the spatial character of the Islamic students in their respective schools. The interview was conducted on Tuesday, July 18, 2017 at SMAN 1 Montong Gading and SMA 1 Sikur and then continued on Wednesday, July 19, 2017 at SMAN 1 Sembalun and SMAN 1 Sambelia district of East Lombok.Adapun result from observation and interview as follows: 
Table 1. Interview result

\begin{tabular}{|c|c|c|c|}
\hline No & $\begin{array}{c}\text { School } \\
\text { name }\end{array}$ & $\begin{array}{l}\text { Teacher } \\
\text { Name }\end{array}$ & Interview result \\
\hline 1 & $\begin{array}{l}\text { SMAN I } \\
\text { Montong } \\
\text { Gading }\end{array}$ & $\begin{array}{l}\text { Lukman } \\
\text { Nurhakim }\end{array}$ & $\begin{array}{l}\text { Knowledge of the various learning models undertaken in shaping } \\
\text { the Islamic character of the students is obtained through training } \\
\text { vessels, seminars mainly from the MGMP district of East Lombok } \\
\text { and the tools used are also made jointly in the MGMP by dividing } \\
\text { all the Basic Competencies according to the number of teachers } \\
\text { available. In general, learning model is done Coorperative Learning } \\
\text { jigsaw. because the Jigsaw learning model can shape the Islamic } \\
\text { character of the students such as teamwork, respect for the opinions } \\
\text { of others, caring for others and high sense of responsibility towards } \\
\text { the team. In every learning Geography always relate the material } \\
\text { with what is in the student environment both natural and social } \\
\text { phenomena so that students can have humanitarian character and } \\
\text { share each other, at the end of learning often give assignment in the } \\
\text { form searching and exploring verses that exist in the Qur'an that has } \\
\text { something to do with the material being studied.In addition SMAN } \\
1 \text { Montong Gading } 3 \text { times a year held Out Baunt with the aim that } \\
\text { students easier to understand the material Geography contextually } \\
\text { and can increase the character of Islami love land water and care for } \\
\text { the environment. The spatial character of Islami conducted by the } \\
\text { students is by planting trees in the school environment as a form of } \\
\text { environmental conservation and as a form of human interaction with } \\
\text { the space in which he lives. }\end{array}$ \\
\hline 2 & $\begin{array}{l}\text { SMAN I } \\
\text { Sikur }\end{array}$ & Hj. Animar & $\begin{array}{l}\text { Knowledge of the various learning models conducted in shaping the } \\
\text { Islamic character of the students is obtained through training } \\
\text { vessels, seminars mainly from the MGMP district of East Lombok, } \\
\text { even on a national scale because he is one of the Nuclear Instructors } \\
\text { and the tools used are also made together in the MGMP by dividing } \\
\text { all Basic Competencies correspond to the number of teachers } \\
\text { available. In the formation of Islamic character the various learning } \\
\text { models recommended in the } 2013 \text { curriculum are used because } \\
\text { SMAN I Sikur has applied the } 2013 \text { curriculum for all levels but the } \\
\text { more commonly used remains Jigsaw because this learning model } \\
\text { makes the students motivated to learn because the scores } \\
\text { contributed by the students to the team are based on the individual } \\
\text { score scoring system and Jigsaw is designed to enhance students' } \\
\text { sense of responsibility independently. In the execution of the } \\
\text { material is studied contextually and is always associated with the } \\
\text { expected character of Islam such as caring for others, caring for the } \\
\text { environment and a high sense of responsibility towards the life of } \\
\text { others. At the end of each lesson there is always an assignment of } \\
\text { observation of the environment around the students to cultivate the } \\
\text { attitude of the environmental caring character and the love of the } \\
\text { country. Spatial character found is that students do not make } \\
\text { garbage in the school environment. Students know that littering can } \\
\text { damage the environment and can cause disaster for humans and for } \\
\text { the environment. }\end{array}$ \\
\hline 3 & $\begin{array}{l}\text { SMAN } 1 \\
\text { Sembalun }\end{array}$ & Rohaiman & $\begin{array}{l}\text { Knowledge of the various learning models undertaken in shaping } \\
\text { the Islamic character of the students is obtained through training } \\
\text { vessels, seminars mainly from the MGMP district of East Lombok } \\
\text { and the tools used are also made jointly in the MGMP by dividing } \\
\text { all the Basic Competencies according to the number of teachers } \\
\text { available. In general, the model of learning is done Coorperative }\end{array}$ \\
\hline
\end{tabular}




\begin{tabular}{|c|c|c|c|}
\hline & & & $\begin{array}{l}\text { Learning jigsaw because Jigsaw learning model can form a } \\
\text { confident character, able to express opinions and appreciate others. } \\
\text { In applying the Jigsaw model is always linking the material being } \\
\text { studied with real life so that the material obtained is more } \\
\text { meaningful and contextual thus will form Islamic character in the } \\
\text { form of love of the homeland and care about the environment, with } \\
\text { the establishment of Islamic character will be able to form the } \\
\text { character of students who can minimize the arrival of negative } \\
\text { external influences. In giving tasks students are asked to observe the } \\
\text { phenomena that exist around the environment and then told to look } \\
\text { for the connection phenomena that occur with the expected Islamic } \\
\text { character and more sometimes sometimes told to connect the } \\
\text { paragraph of verses that exist in the Qur'an to form the character of } \\
\text { environmental care and love the homeland. The Islamic spatial } \\
\text { character is The students do not pick the school flowers } \\
\text { indiscriminately and do not damage the plants in the school yard. } \\
\text { The preservation of fauna is highly dependent on human activities. }\end{array}$ \\
\hline 4 & $\begin{array}{l}\text { SMAN } 1 \\
\text { Sambelia }\end{array}$ & Jamilah & $\begin{array}{l}\text { Knowledge of the various learning models undertaken in shaping } \\
\text { the Islamic character of the students is obtained through training } \\
\text { vessels, seminars mainly from the MGMP district of East Lombok } \\
\text { and the tools used are also made jointly in the MGMP by dividing } \\
\text { all the Basic Competencies according to the number of teachers } \\
\text { available. In general, learning model } \\
\text { can form the character of students who exist in the curriculum of } \\
2013 \text {, especially the Islamic character and even have been designing } \\
\text { in every RPP created because the formation of the value of this } \\
\text { character is very necessary in the daily life of students so that when } \\
\text { students face the influence and challenges from outside the negative } \\
\text { nature of students can already fortify himself with the planting of } \\
\text { existing character values. } \\
\text { In the implementation also always relate the material with the life } \\
\text { environment around students so that students feel the material being } \\
\text { studied contextual and more meaningful and this can lead to the } \\
\text { character of love the homeland and care for the environment. At the } \\
\text { end of the lesson the task of observation in the environment about } \\
\text { the Islamic character that should be emulated and revealed in the } \\
\text { form of reports. The character of Islamic room found that the } \\
\text { students do not throw garbage carelessly. }\end{array}$ \\
\hline
\end{tabular}

Jigsaw learning model can shape the character of students, such as cooperation, respect the opinions of others, communicate verbally well. this model is carried out in the form of a discussion by forming a team of experts drawn from several teams that have been formed. Knowledge of the learning model has been received through various containers such as training and seminars, at least in the MGMP container and the existing learning model in the 2013 curriculum is very powerful for shaping the character of students especially the Islamic character (Nurhakim, 2017). The application of learning model has been done in Geography learning by applying various models recommended in the 2013 curriculum such as applying Jigsaw model and out baunt 3 times a year with the aim of making it easier for students to comprehend the Geography material contextually and can increase the love character of the homeland and caring environment Besides every learning Geography always relate the material with what is in the student environment both in the form of natural and social phenomena so that students can have the character of humanity and share each other, at the end of learning often gives the task of looking for verses in the existing Qur'an relation to the material being studied (Dat, 2016). 
Jigsaw is a learning model used in shaping the character of students such as: daring to express opinions, appreciate the opinions of others and cooperation.Knowledge teachers about the model of learning that can shape the character of students, especially Islamic characters obtained through various training and seminars and transmitted through the MGMP container because this teacher is Nuclear Instructor Geography and stated all the characters expected in the 2013 curriculum is a character that is also expected in Islam, (Animar, 2017). SMAN 1 Sikur has implemented the 2013 curriculum for all levels by applying Islamic character education by applying Jigsaw learning model in the form of CTL, because the learning material of Geography will be more effective and real received by students both naturally and socially. Then at the end of each learning always ends with the assignment of observations in each student's environment in accordance with the material being studied to cultivate the attitude of environmental caring character and love the homeland (Animar, 2017).

Jigsaw learning model is a model that can shape the character of students because this model can cause a confident character, able to express opinions and appreciate others. Knowledge of Geography learning model that can form Islamic character has been obtained through training and MGMP forum and character education strongly supports the formation of student character that can minimize the coming of negative influence outside. Implementation of Geography learning model that can form Islamic character has been implemented in every learning Geography, especially by using Jigsaw learning model and always relate it with real life that exist in the student environment either in the form of natural and social phenomena sehiingga formed in the character of the students in the form of love the homeland and caring environment (Pala, 2011). In principle Jigsaw learning model is able to form the character of students because this model is able to form characters such as cooperation, respect for others and tolerance, this model is done by forming expert team drawn from several existing teams Knowledge of learning models obtained through training venues, seminars, especially MGMP. Learning model that can form the character of students that exist in the curriculum of 2013, especially the Islamic character and even have been designing in every RPP created because the formation of the character value is in need in the daily life of students, so that when students face the influence and challenge from outside the nature negative students have been able to fortify themselves by planting the value of existing characters, while the form of learning models that have been applied is to vary the existing learning models in the curriculum 2013 in accordance with the material being studied (Miaz, 2015). To see the inconsistency ratio of each spatial Islamic character can be analyzed with AHP. In AHP data processing, the easier way to do this weighting is to use the help of computer program (Expert Choice).

The spatial character of Islami is Spatial Character is a way of view or analytical framework that emphasizes the existence of space as emphasis. Space eksisitensi in the perspective of geography can be viewed from the structure (spatial structure), pattern (spatial pattern), and process (spatial processess). In this spatial character that needs to be considered is the spread of space usage and the provision of space that will be utilized. Analysis with the approach of human activity is describing human activity in space that emphasizes the religious aspect. Character keruanga that is formed is the character of spatial Islami done by students is to plant trees in the school environment sabagai form of environmental conservation and as a form of human interaction with the space in which he stays. Students do not make garbage in the school environment. Students know that littering can damage the environment and can cause disaster for humans and for the environment. Students do not pick school flowers indiscriminately and do not damage plants in the school yard. The preservation of fauna is highly dependent on human activities.

\section{Conclusion}

The implementation of Islamic character education in high school in East Lombok Regency is generally done with the same learning model because the Learning Implementation Plan (RPP) is designed 
and designed by teachers in the MGMP container in East Lombok regency. The learning model that is often used is Cooperarive Learning type Jigsaw. The Islamic characters formed in the Jigsaw learning model are teamwork, caring, respectful of other people's opinions, responsible, and independent. The spatial character of Islami conducted by the students is by planting trees in the school environment as a form of environmental conservation and as a form of human interaction with the space in which he lives. Students do not make garbage in the school environment. Students know that littering can damage the environment and can cause disaster for humans and for the environment. Students do not pick school flowers indiscriminately and do not damage plants in the school yard. The preservation of fauna is highly dependent on human activities.

\section{References}

Anwar, Syafri. (2017). The Mapping Of Disaster Readiness of SSB (The Disaster Ready Schools) in The Coastal Area Of Padang City, Indonesia. Sumatra Journal of Disaster, Geography and Geography Education ISSN: 2580-4030 (Print) 2580-1775 (Online) Vol 1, No. 1, (pp. 7-14), June, 2017 http://sjdgge.ppj.unp.ac.id

Ancok, Djamaludin dan Fuat NashoriSuroso. (1995). Psikologi Islami. Yogyakarta: Pustaka Pelajar.

BPS. (2006). Provinsi Nusa Tenggara Barat Dalam Angka: Pemprov NTB

BPS. (2010). Kabupaten Lombok Timur dalam Angka. Pemkab. Lombok Timur

Ernawati. (2015). Perilaku peduli Lingkungan pada Sekolah Alam di Kota Padang, Disertasi, Program Pasca sarjana Universitas Negeri Padang

Ernawati. (2017). Pelajaran Geografi untuk membentuk karakter Islami pada daerah destinasi wisata halal kasus kabupaten Lombok Timur, Program Pasca sarjana Universitas Negeri Padang

Faisal .Sanahpiah. (1990). Penelitian Aplikasi Dasar dan Aplikasi, Malang: Yayasan Asih, Asah dan Asuh

Ikwumelu, S, N. Mbang Ekpo Bassey, Ogene. A. Oyibe. (2015). Social Studies Education And The Need For Value-Based Education In Nigeri. Published by European Centre for Research Training and Development UK. No.11, pp.63-74, November 2015.

James arthur, Kristian Krisjanson, David Walker, Wouther Sanders, Chantel Jones. (2013). Character Education in UK schools. University Of Brimingham. ISBN:978-0-7944-2852-2.

Jamaluddin, Dindin. (2013). Character Education, Internastonal Journal Of Scientific and Technology Research Vol2 ISSUE 2, FEBRUARY 2013 ISSN 2277-8616

Lukman Abu, Mahani Mokhtar, Zinudin Hassan, and Siti Zkiah Darmita Suhan. (2015). How to Develop Character of Madrasah Studen in Indonesia. Journal Of Education and Learning. Vol.9 (1) pp. 79.86.

Miaz, Yalvema. (2015). Improving Student's Achievement Of Social Science By Using Jigsaw Cooperative Learning Model at Primary School. IOSR Journal of Research \& Method in Education (IOSR-JRME) e-ISSN: 2320-7388,p-ISSN: 2320-737X Volume 5, Issue 4 Ver. II (Jul - Aug. 2015), PP 01-07

Miles, M.B \& Huberman, A, M. (1994). Analisis Data Kualitatif (Buku Sumber tentang metode metode baru) Terjemahan oleh Tjetjep Rohendi Rohidi, Jakarta Penerbit Universitas Indonesia

Moleong. (2004). Metode Penelitian Kualitatif, Bandung: PtRemajaRosdaKarya

Nasution, S. (1989). Kurikulum dan Pengajaran. Bandung: Bina Aksara .

Pala, Aynur. (2011). The Need For Character Education. Internasional Journal Of Soscial Sciences And Humanity Studies Vol 3, No 2, 2011 ISSN: 1309-8063 (Online)

Sugandi, Dede. (2015). "Pembelajaran Geografi sebagai Salah Satu Dasar Pembentukan Karakter Bangsa" in SOSIOHUMANIKA: Jurnal Pendidikan Sains Sosial dan Kemanusiaan, Vol.8(2) November, pp.241-252. Bandung, Indonesia: Minda Masagi Press and UNIPA Surabaya, ISSN 1979-0112.

Sarah Bernarz. (2000). Geography Education Research in The Journal Of Geography 1988-1997. Departmen Of Geography, Texas A and M University, College Station TX 77843-4147, USA. Internasional Research in Gepgraphycal and Enviromental Education . Vol.9. No 2, 2000. 
Saragih, B and S. Satywan. (2001). "Lake Toba; The Need for an Integrtaed Management System". Annual Tourism Research 23 (1): 110-121.

Tran Van Dat. (2016). The Effect Of Jigsaw Learning On Student's Knowledge Retention in Vitnamese Higher Education. International Journal of Higher Education Vol. 5, No. 2; 2016.

Utomo, Prasetio, Eko. (2016). Internalisasi Nilai-Nilai Karakter Dalam Pembelajaran Ips Pada Siswa Smp Negeri Model Terpadu Bojonegoro. Metafora, Volume 2, Nomor 2, April 2016 (91-104) Online, 